I Clin Microbiol Infect Dis 1995;14:1090-1094.

19. Jalava J, Mantymaa ML, Ekblad U, Toivanen P, Skurnik M, Lassila O, et al. Bacterial 16S rDNA polymerase chain reaction in the detection of intra-amniotic infection. Br J Obstet Gynaecol 1996;103:664-669.

20. Heritz DM, Lacroix JM, Batra SD, Jarvi KA, Beheshti B, Mittelman MW. Detection of eubacteria in interstitial cystitis by $16 \mathrm{~S}$ rDNA amplification. J Urol 1997;158:2291-2295.

21. Arlet G, Philippon A. PCR-Based Approaches for the Detection of Bacterial Resistance. Ehrlich GD, Greenberg SJ, eds. Blackwell Scientific Publications; 1994.

22. Courvalin P. Genotypic approach to the study of bacterial resistance to antibiotics. Antimicrob Agents Chemother 1991;3:1019-1023.

23. Persing DH, Relman DA, Tenover FC. Genotypic Detection of Antimicrobial Resistance. Persing D, ed. Washington, DC: ASM Press; 1996.

24. Tenover FC. Bauer and Kirbey meet Watson and Crick: antimicrobial testing in the molecular era. ASM News 1992;58;669-672.

25. Jacoby GA. Extended-spectrum beta-lactamases and other enzymes providing resistance to oxyimino-beta-lactams. Infect Dis Clin North Am 1997;11:875-887.

26. Arthur M, Molinas C, Mabilat C, Courvalin P. Detection of erythromycin resistance by the polymerase chain reaction using primers in conserved regions of erm rRNA methylase genes. Antimicrob Agents Chemother 1990;34:2024-2026.

27. Coffey TJ, Daniels M, McDougal LK, Dowson CG, Tenover FC, Spratt BG. Genetic analysis of clinical isolates of Streptococcus pneumoniae with high-level resistance to expanded spectrum cephalosporins. Antimicrob Agents Chemother 1995;3:1306-1313.

28. Acar JF, Goldstein FW. Trends in bacterial resistance to fluoroquinolones. Clin Infect Dis 1997;24(suppl 1):S67-S73.

29. Fodor SP, Rava RP, Huang XC, Pease AC, Holmes CP, Adams CL. Multiplexed biochemical assays with biological chips. Nature 1993;364:555556.
30. Lipshutz RJ, Morris D, Chee M, Hubbell E, Kozal MJ, Shah N, et al Using oligonucleotide probe arrays to access genetic diversity. Biotechniques 1995;19:4427.

31. Chambers H. Methicillin resistance in staphylococci: molecular and biochemical basis and clinical implications. Clin Microbiol Rev 1997;10: 781-791.

32. Michel M, Gutmann L. Methicillin-resistant Staphylococcus aureus and vancomycin-resistant enterococci: therapeutic realities and possibilities. Lancet 1997;349:1901-1906.

33. Carroll KC, Leonard RB, Newcomb-Gayman PL, Hillyard DR. Rapid detection of the staphylococcal mecA gene from BACTEC blood culture bottles by the polymerase chain reaction. Am J Clin Pathol 1996;106: 600-605.

34. Wallet F, Roussel-Delvallez M, Courcol RJ. Choice of a routine method for detecting methicillin resistance in staphylococci. I Antimicrob Chemother 1996;37:901-909.

35. Arthur M, Reynolds P, Courvalin P. Glycopeptide resistance in enterococci. Trends Microbiol 1996;4:401-407.

36. Poyart C, Pierre C, Quesne G, Pron B, Berche P, Trieu-Cuot P. Emergence of vancomycin resistance in the genus Streptococcus: characterization of a vanB transferable determinant in Streptococcus bovis. Antimicrob Agents Chemother 1997;41:24-29.

37. Dutka-Malen S, Evers S, Courvalin P. Detection of glycopeptide resistance genotypes and identification to the species level of clinically relevant enterococci by PCR. J Clin Microbiol 1995;33:1434.

38. Patel R, Uhl JR, Kohner P, Hopkins MK, Cockerill FR III. Multiplex PCR detection of $\operatorname{van} \mathrm{A}, \operatorname{van} \mathrm{B}, \operatorname{van} \mathrm{C}-1$, and $\operatorname{van} \mathrm{C}-2 / 3$ genes in enterococci. $J$ Clin Microbiol 1997;35:703-707.

39. Perichon B, Reynolds P, Courvalin P. VanD-type glycopeptide-resistant Enterococcus faecium BM4339. Antimicrob Agents Chemother 1997;41:2016-2018

\title{
Epidemiology of a Dominant Clonal Strain of VRE at Two Hospitals in Boston
}

\section{Gina Pugliese, RN, MS Martin S. Favero,PhD}

Dr. Scott Fridkin and colleagues from the Massachusetts General Hospital in Boston recently reported on a strain of vancomycin-resistant Enterococcus faeci$u m$ in two hospitals. In 1996, the dominant (43\%) strain of vancomycin-resistant enterococci (VRE; type A) at Massachusetts General Hospital was identified at Brigham and Women's Hospital (BWH).

To characterize the epidemiology of infection with type A isolates of VRE at $\mathrm{BWH}$, the investigators collected demographic and clinical data for all patients from whom VRE were isolated from a clinical specimen through September 1996. The first clinical isolates from all BWH patients were typed by pulsed-field gel electrophoresis of SmaI digests of chro- mosomal DNA. Among patients hospitalized after the first patient at BWH infected with a type A isolate of VRE was identified, exposures were compared between patients who acquired type $\mathrm{A}$ isolates of VRE and those who acquired other types of VRE.

Three months after the index patient arrived at $\mathrm{BWH}$ and at a time when at least 12 strains of VRE were present, type A isolates of VRE became dominant; 39 (52\%) of 75 of the study cohort had acquired type A isolates of VRE. They found no association between the acquisition of type $A$ isolates of VRE and transfer from another institution or temporal overlap by service, ward, or floor with patients known to have type A isolates. By multivariate analysis, only residence in the medical intensive-care unit (adjusted odds ratio [OR], 3.2; 95\% confidence interval $\left.\left[\mathrm{CI}_{95}\right], 1.4-107\right)$ and the receipt of two or more antibiotics per patient day (adjusted OR, 12.2; $\mathrm{CI}_{95}, 1.2-$ 9.0) were associated with the acquisition of strain A.

This strain of VRE, dominant at two Boston hospitals, was associated with intensity of antibiotic exposures (ie, two or more antibiotics per patient day). The authors hypothesize that this strain may have unidentified properties providing a mechanism favoring its spread and dominance over other existing isolates, and further studies are needed to define these properties.

FROM: Fridkin SK, Yokoe DS, Whitney CG, Onderdonk A, Hooper DC. Epidemiology of a dominant clonal strain of vancomycin-resistant Enterococcus faeci$u m$ at separate hospitals in Boston, Massachusetts. J Clin Microbiol 1998; 36:965-970. 